\title{
Pengaruh Rumpun Domba Terhadap Lama Waktu Makan dan Lama Ruminasi
}

\author{
A. Subhan ${ }^{1, a}$, K. A. Kamil ${ }^{2}$, D. Heriyadi ${ }^{2}$ \\ ${ }^{1}$ Mahasiswa Program Studi Pascasarjana Fakultas Peternakan Universitas Padjadjaran \\ ${ }^{2}$ Dosen Program Studi Pascasarjana Fakultas Peternakan Universitas Padjadjaran \\ a) Korespondensi: arsya4u@gmail.com
}

\begin{abstract}
Abstrak
Penelitian ini bertujuan untuk mengetahui perbedaan lama makan dan lama ruminasi dari tiga rumpun domba yaitu Domba Garut, Domba Priangan, dan Domba Lokal dengan umur $12-18$ bulan. Rataan bobot badan setiap rumpun domba yaitu DG $34 \mathrm{~kg}$, DP $21 \mathrm{~kg}$, dan DL 20,5 kg. Setiap rumpun domba dianggap sebagai perlakuan dan masing - masing diulang sebanyak enam kali. Domba dipelihara dalam kandang individu yang telah dipasang kamera CCTV sebanyak dua unit. Pakan berupa hijauan segar dan air minum, diberikan secara ad libitum selama periode penelitian (06:00-18:00 WIB). Rangcangan acak lengkap digunakan dalam penelitian ini, selanjutnya data diolah dengan ANOVA melalui uji F dengan Uji Duncan sebagai uji lanjutnya. Penelitian dilaksanakan di Laboratorium Ternak Potong Kandang Domba Fakultas Peternakan Universitas Padjadjaran sejak 29 Januari hingga 12 April 2019. Hasil penelitian menunjukkan terdapat perbedaan lama waktu makan dan ruminasi antar rumpun domba. Domba Lokal menunjukkan lama waktu makan paling sebentar setelah Domba Garut dan Domba Priangan (DL 8996,00 detik/hari, DG 13483,33 detik/hari, dan DP 16468,67 detik/hari). Lama ruminasi paling lama ditunjukkan oleh Domba Garut (16993,67 detik/hari), kemudian Domba Priangan (13718,33 detik/hari), dan paling sebentar Domba Lokal (11163,67 detik/hari). Kesimpulan dari penelitian ini adalah terdapat perbedaan lama waktu makan dan lama ruminasi dari ketiga rumpun domba.

Kata kunci : Lama Makan, Lama Ruminasi, Domba Garut, Domba Priangan, Domba Lokal
\end{abstract}

\section{Sheep Tribe Effect to Eating and Ruminating Time}

\begin{abstract}
Abstrack
This study aimed to learn about differentiation of eating and ruminating time from three tribe of sheep which is Garut's Sheep, Priangan's Sheep, dan also Local's Sheep. Every sheep has equal age from 12 to 18 month with average body weigth $34 \mathrm{~kg}$ 's for Garut's Sheep, $21 \mathrm{~kg}$ 's for Priangan's Sheep, and $20 \mathrm{~kg}$ 's for Local's Sheep. Each tribe of sheep was used as a treatment, and every treatment has repeated six times. Two CCTV's was used to observe the behaviour of sheep with modified individual cage along observation. Observation period was start from 06:00 to 18:00 for each individual with ad libitum forages as primary food and water supply. The data were randomized using Complete Randomized Sampling Method, and evaluated using ANOVA with Duncan post-hoc test to determine the divergency. The research was held in "Laboratorium Ternak Potong Kandang Domba Fakultas Peternakan Universitas Padjadjaran" since January $29^{\text {th }}$ 2019 until April $12^{\text {th }} 2019$. The result show that every tribe has different number of the time spend for eat and ruminate. Local's Sheep has the lowest eating time after Garut's Sheep and Priangan's Sheep with value 8996,00 s/d, 13483,33 s/d, and 16468,67 s/d respectively. Garut's Sheep has the higest time number of rumination with 16993,67 s/d, and then Priangan's Sheep and Local's Sheep with value $13718,33 \mathrm{~s} / \mathrm{d}$, and $11163,67 \mathrm{~s} / \mathrm{d}$ respectively. Sheep tribe has influence eating time and rumination time.
\end{abstract}

Keywords : Eating Time, Ruminating Time, Garut's Sheep, Priangan Sheep's, Local's Sheep 


\section{Pendahuluan}

Jawa barat merupakan sentra peternakan domba di Indonesia, dengan populasi daerah pada tahun 2017 yaitu 10,714 juta ekor sedangkan populasi domba secara nasional sebesar 16,462 juta ekor (Direktorat Jendral Peternakan dan Kesehatan Hewan, 2018). Kemampuannya beradaptasi dengan berbagai macam kondisi lingkungan pada iklim tropis, sifat reproduksi, dan kemampuannya untuk mencerna pakan berserat kasar tinggi, menjadikan ternak ini lebih mudah untuk dipelihara. Peningkatan populasi ternak domba sangat diperlukan, dalam upaya pemenuhan kebutuhan masyarakat yang semakin hari semakin meningkat. Domba Priangan dan Domba Lokal ditujukan terutama untuk dimanfatkan dagingnya sedangkan, Domba Garut diternakan sebagai sarana seni budaya dan keagamaan sehingga memiliki nilai ekonomis lebih tinggi.

Domba Garut adalah domba yang memiliki kombinasi daun telinga rumpung atau ngadaun hiris dengan ekor ngabuntut bagong atau ngabuntut beurit (SNI 7532, 2009). Bobot tubuh Domba Garut pada usia yearling sebesar $36,43 \pm 1,45 \mathrm{~kg}$ (Wijaya, dkk, 2016) sedangkan pada umur $9-10$ bulan memiliki rataan bobot badan 20 kg/ekor (Budiman, 2006). Domba Garut sebagai salah satu asset sumber daya genetik ternak asli yang sangat penting di Provinsi Jawa Barat perlu dilestarikan, dibudidayakan, dan dimanfaatkan untuk mendapatkan manfaat ekonomi yang optimum terutama bagi masyarakat peternak Domba Garut (Heriyadi, 2011).

Penetapan rumpun Domba Priangan telah dilakukan oleh Menteri Pertanian Republik Indonesia (2017) melalui Keputusan Menteri Pertanian Republik Indonesia Nomor 300/Kpts/SR.120/5/2017 yang menyatakan bahwa Domba Priangan sebagai kekayaan sumber daya genetik ternak lokal Indonesia, harus dilindungi dan dilestarikan, serta mempunyai bentuk fisik dan komposisi genetik yang khas dibandingkan dengan rumpun domba lainnya. Deskripsi Domba Priangan yaitu kombinasi antara ekor ngabuntut beurit atau ngabuntut bagong dengan telinga rubak (Heriyadi, 2011 yang disitasi oleh Heriyadi, 2013). Domba Priangan muda ( \pm bulan) memiliki rataan bobot badan $21,7 \pm 3,25 \mathrm{~kg}$ (Supratman, dkk, 2016) sedangkan, pada umur 1-2 tahun disarankan memiliki rataan bobot badan 27,3 $\pm 3,1 \mathrm{~kg}$ (Menteri Pertanian Republik Indonesia. 2017).

Produktifitas seekor ternak sangat dipengaruhi oleh dua faktor utama yaitu genetik dan lingkungan. Faktor genetik menentukan kemampuan produksi, sedangkan lingkungan merupakan faktor pendukung agar ternak mampu berproduksi sesuai dengan kemapuannya (Tama, dkk, 2016). Tingkah laku ternak sebagai salah satu dasar dari potensi genetik sangat penting untuk diketahui, karena mengerti tentang tingkah laku domba dapat memudahkan dalam penanganan domba (Bamualim, 2008 yang disitasi oleh Muhammad, dkk, 2014). Tingkah laku ternak merupakan potensi genetis bersifat herediter, dapat dipelajari lebih lanjut, dengan tujuan untuk mendapatkan manfaat maksimal dari setiap rumpun ternak tetapi, dapat dimanipulasi dengan cara memberikan pelatihan khusus (Tiesnamurti dan Subandriyo, 2005). Karakteristik tingkah laku makan (ingestif) dapat digunakan sebagai peubah untuk membedakan rumpun domba (Handiwiriawan, dkk, 2014).

Tingkah laku ingestif meliputi makan atau merumput (prehensi, mastikasi, dan deglutisi), minum, ruminasi, dan menjilat (Soeharsono, 2010). Prehensi adalah suatu proses gerakan untuk meperoleh (mengambil) pakan dan memasukkannya ke dalam mulut (Soeharsono, 2010). Mastikasi atau pengunyahan biasanya segera mengikuti proses prehensi (Frandson, 1993). Proses mastikasi yaitu, terjadinya proses penghancuran makanan secara mekanis, diikuti dengan sekresi saliva sebesar 23\% dari total salivasi yang terjadi dalam mulut domba (Minervino et al., 2014). Penelanan (deglutisi) ialah perjalanan makanan dari mulut melalui pharynx dan oesophagus sampai kedalam lambung (Soeharsono, 2010).

Ruminasi atau pengunyahan kembali terdiri atas tiga tahap yakni : (1) tahap regurgitasi atau pengeluaran kembali bahan makanan dari rumen kedalam mulut, (2) tahap remastikasi yang dikenal dengan proses memamah biak, dan (3) tahap redeglutisi atau penelanan kembali bahan 
yang sudah digiling ulang masuk ke dalam rumen atau langsung ke retikulum (Soeharsono, 2010). Lama waktu yang digunakan untuk ruminasi biasanya lebih Panjang dan ternak lebih sering melakukan ruminasi untuk memudahkan mencerna makanan tersebut dalam saluran pencernaannya (Kusuma, dkk, 2015).

Perbedaan lama waktu makan dan lama ruminasi pada beberapa rumpun pada rusa, disebabkan oleh perbedaan rumpun, bobot badan, dan pakan yang diberikan dimana, terdapat indikasi bahwa aktifitas ruminasi rusa dibandingkan domba relatif sama (Afzalani, 2008). karakteristik tingkah laku makan khususnya dari ketiga rumpun domba tersebut belum banyak diketahui maka, pendekatan lain digunakan terutama ditinjau dari bobot tubuh domba. Rumpun domba yang akan diamati memiliki karakteristik dan ukuran tubuh yang khas, ditinjau dari besaran standar ukuran tubuh pada umur yang sama. Setiap kenaikan ukuran tubuh maka akan diikuti kenaikan tubuh lainnya (Soeparno, 1992). Saluran - saluran pencernaan yang berada dalam abdomen menyumbang $10-25 \%$ dari bobot hidup ternak (Dalton, 1984). Ukuran tubuh ini akan mempengaruhi perbedaan kebutuhan ransum dari masing-masing rumpun. Karakter produksi dari setiap rumpun juga ikut mempengaruhi pola makan, dan akan mempengaruhi terhadap perbedaan lama waktu makan dan lama ruminasinya.

\section{Bahan dan Metode Bahan}

Penelitian ini menggunakan masingmasing dua ekor domba untuk setiap rumpun pada umur yearling. Rumpun domba yang dimaksud adalah, Domba Garut (BB 35,0 $\mathrm{Kg}$ ), Domba Priangan (BB 21,5 Kg), dan Domba Lokal (BB 20,5). Setiap individu domba akan diamati sebanyak tiga kali pengamatan, sehingga didapatkan enam kali ulangan untuk setiap rumpun domba. Masa adaptasi minimal selama satu minggu untuk setiap ekor domba. Selama periode adaptasi, setiap domba diberikan obat cacing oral dalam upaya pencegahan penyakit, dan adaptasi terhadap pakan dan lingkungan dilakukan (Susiloningsih, 2008). Pakan berupa hijauan segar dan air minum diberikan secara ad libitum (selalu tersedia).
Kandang yang digunakan adalah kandang individu dengan luas masing-masing kandang $0,55 \mathrm{~m}^{2}$ dan sudah disesuaikan pada bagian sisi sebelah kiri dan bak pakan, agar dapat digunakan untuk merekam kegiatan makan domba. Suhu didalam kandang terendah $21^{\circ} \mathrm{C}$ hingga tertinggi $30^{\circ} \mathrm{C}$. Perekaman dilakukan dengan menggunakan $C C T V$ set yang terdiri dari dua unit kamera $C C T V$, satu unit $D V R$, dan satu unit $H D D$ (memori) berkapasitas 1 Terabyte. Evaluasi hasil perekaman dilakukan dengan menggunakan Timer untuk mengetahui lama waktu makan dan lama waktu ruminasinya. Alat tulis, program Microsoft Excel, dan program SPSS yang digunakan untuk mencatat dan mengolah data.

\section{Metode}

Penelitian ini dilaksanakan di Kandang Domba Laboratorium Ternak Potong Fakultas Peternakan Universitas Padjadjaran sejak tanggal 07 Februari 2019 hingga 14 April 2019. Pengambilan sampel dilakukan secara purposive sampling, dengan pertimbangan keseragaman jenis kelamin (jantan) dan umur ternak (yearling) (Sudjana, 2005). Metode penelitian yang digunakan yaitu metode eksperimental dengan menggunakan Rancangan Acak Lengkap (RAL). Sampel yang digunakan pada penelitian ini adalah domba jantan umur yearling dari tiga rumpun domba yaitu, Domba Garut, Domba Priangan, dan Domba Lokal. Setiap rumpun domba akan diamati sebanyak enam kali (ulangan). Perolehan data dianalisa menggunakan analisis sidik ragam (Anova), dan untuk mengetahui pengaruh antar perlakuan dilakukan uji Duncan sebagai uji lanjut (Harsojuwono, dkk, 2011).

Setiap Penarikan data dilakukan pada saat domba makan siang hari, sejak pukul 06:00 hingga 18:00 WIB (Nugroho, et al, 2015; Kusuma, et al, 2015). Lama waktu makan dihitung sejak pertama kali domba merenggut makanan (prehensi), hingga penelanan (deglutisi) tanpa lanjutan prehensi. Lama waktu ruminasi dihitung sejak pertama kali bolus dimasukkan ke mulut sampai bolus tidak lagi keluar (Kusuma, dkk, 2015). 


\section{Hasil dan Pembahasan}

Hasil penelitian menunjukkan terdapat perbedaan siginifikan $(\mathrm{P}<0,05)$ lama waktu makan antar rumpun domba. Lama waktu makan berturut-turut dari yang tertinggi hingga terendah yaitu, Domba Priangan (16468,67 detik/hari), Domba Garut (13483,33 detik/hari), dan Domba Lokal (8996,00 detik/hari). Das et al, (1999) menjelaskan lama waktu makan domba pada pengamatan selama 24 jam sekitar 420 menit, nilai tersebut berbeda dengan hasil penelitian selama 12 jam.

Faktor lingkungan yaitu ukuran kandang dan hijauan pakan yang diberikan pada kondisi yang seragam, untuk memeperkuat homogenitas manajemen pemeliharaan domba penelitian. Suhu di dalam kandang selama penelitian relative stabil antara $21^{\circ} \mathrm{C}$ hingga $30^{\circ} \mathrm{C}$, sehingga tidak memungkinkan untuk memberikan pengaruh terhadap konsumsi pakan (Susiloningsih, dkk, 2008). Perbedaan lama waktu makan terutama terlihat pada karakteristik domba tersebut saat makan. Selengkapnya dapat dilihat pada Tabel 1 .

Ketersediaan cahaya selama penelitian siang hari, relatif sama, sehingga tidak memungkinkan adanya pengaruh cahaya terhadap lama waktu makan. Nugroho, dkk (2015) menjelaskan terdapat lama waktu makan antara siang dan malam hari akibat dari ketersediaan cahaya. Karakter makan setiap rumpun domba dapat dilihat terutama dari lama waktu makannya. Domba Priangan lebih selektif dalam memilih makanan sehingga waktu untuk melakukan prehensi lebih lama jika dibandingkan dengan kedua rumpun domba lainnya. Kusuma, dkk, (2015) menjelaskan, pada Sapi Bali yang dipelihara di tempat berbeda, menunjukkan perbedaan lama waktu makan karena, tingkat selektifitas ternak terhadap pakan yang disukai (palatabilitas) berbeda. Domba Garut memiliki karakter tersendiri yaitu, pola makan lebih stabil, lebih toleran terhadap pakan, dan relatif tenang ketika melakukan kegiatan ingestif (makan). Domba lokal tidak terlalu selektif dalam memilih makanan sehingga waktu yang dibutuhkan untuk makan paling sedikit diantara ketiga rumpun tersebut.

Tingkah laku istirahat dengan duduk berbaring dan juga tertidur lebih banyak dilakukan antara pukul 10:00 hingga pukul 14:00 WIB. Terbatasnya waktu pengamatan selama 12 jam, menyebabkan keterkaitan antara satu tingkah laku dengan tingkah laku lainnya. Lama waktu makan juga dipengaruhi oleh kecepatan mengunyah dan menelan. Semakin cepat pengunyahan pakan pada jumlah yang sama maka, waktu makan akan lebih cepat, begitu pula sebaliknya.

Ketiga rumpun domba yang diuji memiliki lama waktu ruminasi yang berbeda nyata $(\mathrm{P}<0,05)$. Domba Garut menunjukkan waktu ruminasi paling lama (16993,67 detik/hari), lalu Domba Priangan (13718,33 detik/hari), dan terakhir Domba Lokal (11163,67 detik/hari). Ruminansia kecil menghabiskan 6-8 jam/hari selama 24 jam dengan waktu maksimum $10 \mathrm{jam} /$ hari untuk melakukan ruminasi (Minervino et al, 2014). Sejalan dengan hal tersebut, Das et al, (1999) melaporkan bahwa domba melakukan aktifitas ruminasi selama $180 \mathrm{menit} /$ hari dengan rincian 120 menit ruminasi saat berbaring dan 60 menit ruminasi saat berdiri. Hasil pengamatan menunjukkan bahwa setiap kali aktifitas ruminasi dilakukan maka domba akan langsung berbaring. Perbedaan lama waktu ruminasi selengkapnya disajikan pada Tabel 2.

Tabel 1. Nilai Minimum, Rata-rata, dan Maksimum Lama Waktu Makan Tiga Rumpun Domba.

\begin{tabular}{lllll}
\hline No. & Rumpun Domba & \multicolumn{3}{l}{ Lama Waktu Makan (detik/hari) } \\
\cline { 3 - 5 } & & Minimum & Rata-rata & Maksimum \\
\hline $\mathbf{1}$ & Domba Priangan & 15388,00 & $16468,67^{*}$ & 17540,00 \\
$\mathbf{2}$ & Domba Garut & 11137,00 & $13483,33^{*}$ & 16116,00 \\
$\mathbf{3}$ & Domba Lokal & 7296,00 & $8996,00^{*}$ & 10348,00 \\
\hline
\end{tabular}

$*=$ Hasil berbeda nyata $\mathrm{P}<0,05$ 
Tabel 2. Nilai Minimum, Rata-rata, dan Maksimum Lama Waktu Makan Tiga Rumpun Domba.

\begin{tabular}{cllll}
\hline \multirow{2}{*}{ No. } & Rumpun Domba & \multicolumn{3}{c}{ Lama Waktu Ruminasi (detik/hari) } \\
\cline { 3 - 5 } & & Minimum & Rata-rata & Maksimum \\
\hline $\mathbf{1}$ & Domba Garut & 14149,00 & $16993,67^{*}$ & 19911,00 \\
$\mathbf{2}$ & Domba Priangan & 11987,00 & $13718,33^{*}$ & 15481,00 \\
$\mathbf{3}$ & Domba Lokal & 10410,00 & $11163,67^{*}$ & 12462,00 \\
\hline
\end{tabular}

* = Hasil berbeda nyata $\mathrm{P}<0,05$

Kegiatan ruminasi juga berkaitan dengan kegiatan makan, karena ketika ternak aktif makan, kegiatan ruminasi akan dihentikan (Nugroho, dkk, 2015). Minervino et al, (2014) menjelaskan bahwa pada kandungan konsentrat yang berbeda, berpengaruh terhadap lama ruminasi domba sedangkan, pakan yang diberikan seragam sehingga, lama waktu ruminasi pada penelitian ini lebih dipengaruhi oleh perbedaan rumpun domba.

Aktifitas ruminasi terjadi secara teratur setelah kegiatan makan berakhir. Hasil pengamatan menunjukkan, Domba Garut memiliki karakteristik ruminasi yang berbeda dari kedua rumpun domba lainnya terutama dilihat dari temperamen domba di dalam kandang yang lebih stabil. Domba Priangan lebih banyak melakukan aktifitas makan dan lebih cepat merespon kondisi lingkungan, sehingga berpengaruh terhadap lama waktu ruminasinya, sedangkan Domba Lokal lebih cenderung konstan dalam melakukan aktifitas lain, terutama istirahat setelah ruminasi sehingga lama ruminasi lebih stabil.

\section{Kesimpulan}

Terdapat perbedaan lama waktu makan dari ketiga rumpun domba. Berturut-turut dari yang terbanyak hingga tekecil yaitu Domba Priangan, Domba Garut, dan Domba Lokal. Lama waktu ruminasi pada ketiga rumpun domba berbeda nyata. Berturut-turut dari yang terbanyak hingga terkecil yaitu Domba Garut, Domba Priangan, dan Domba Lokal. Berdasarkan hasil pengamatan, karakter tingkah laku dari ketiga rumpun menunjukkan perbedaan yang perlu dikaji lebih lanjut.

\section{Ucapan Terimakasih}

Pelaksanaan penelitian ini tidak terlepas dari peran serta berbagai pihak yang terkait sebagai rangkaian dari penulisan makalah
Thesis Program Studi Pascasarjana, Produksi Ternak. Pendanaan yang digunakan berasal dari dana mandiri bersama antara anggota tim penelitian. Penulis mengucapkan terimakasih kepada Dr. Ir. Denie Heriyadi, S.U. selaku pembimbing utama dan Dr. Ir. Kurnia A. Kamil, M.Agr.Sc., M.Phil. selaku pembimbing anggota untuk bimbingannya. Kepada Bapak Andang, SP., dan Tony Pramulyandi, S.Pt., M.I.L. sebagai laboran Laboratorium Produksi Ternak Potong yang telah memberikan bantuan teknis dan peralatan perkandangan. Anggia R. Suryadarma, Eris Eryawanti, M. Mukhlis, Regina Nurfasa Putri, sebagai bagian dari tim penelitian tingkah laku ternak.

\section{Daftar Pustaka}

Afzalani, R. A. Muthalib, dan E. Musnandar. 2008. Preferensi Pakan, Tingkah Laku Makan dan Kebutuhan Nutrien Rusa Sambar (Cervus unicolor) dalam Usaha Penangkaran di Provinsi Jambi. Media Peternakan Vol. 31 No. 2 Hal: 114-121. ISSN 0126-0472.

Budiman, Hadi. 2006. Perbaikan Manajemen Pakan dalam Penggemukan Domba Ditingkat Petani. Temu Teknis Nasional Tenaga Fungsional Pertanian 2006. Pusat Penelitian dan Pengembangan Peternakan. Hal 31-35.

Dalton, D. C. 1984. An introduction to practical animal breeding. Granada Publishing, Ltd. London.

Das, N., D. N. Maitra, G. S. Bisht. 1999. Genetic and non-Genetic Factors Influencing Ingestive Behavior of Sheep Under Stall-Feeding Conditions. Elsevier Science. Small Ruminant Research 32. p.129-136. 
Direktorat Jenderal Peternakan dan Kesehatan Hewan. 2018. Buku Statistik 2017. http://ditjenpkh.pertanian.go.id/user files/File/Buku_Statistik_2017_(eb ook).pdf?time $=1505127443012$. (tersedia, 05-07-2018)

Frandson, R. D. 1993. Anatomi dan Fisiologi Ternak, Edisi Keempat. Gajah mada University Press. Yogyakarta. Hal. 527-547; 600-601. Handiwiriawan, E., Noor R. R., Sumantri C., Subandriyo. 2014. Pemanfaatan Karakteristik Tingkah Laku Dalam Pendugaan Jarak Genetik Antar Rumpun Domba. JITV 19(4): Hal. 239-247.

Harsojuwono, Bambang A., I wayan Arnata, dan Gusti Ayu Kadek D. P. 2011. Rancangan Percobaan Teori, Aplikasi SPSS dan Excel. Lintas Kata Publishing. Jakarta. Hal: 1012.

Heriyadi, D. 2011. Pernak Pernik dan Senarai Domba Garut. UNPAD Press. Bandung. Hal. 1-20.

Heriyadi, D., A. Nurmeidiansyah, dan R. Setiawan. 2013. Inisiasi Titik Tumbuh dan Pengembangan Peternakan Domba Berbasis VBC di Jawa Barat.

Minervino,

A.H.H.,

C.M.

Kaminishikawahara, F.B. Soares, C.A.S.C. Araújo, L.F. Reis, F.A.M.L. Rodrigues, T.A.F. Vechiato, R.N.F. Ferreira, R.A. Barrêto-Júnior, C.S. Mori, E.L. Ortolani. 2014. Behaviour of Confined Sheep Fed with Different Concentrate Sources. Arq. Bras. Med. Vet. Zootec. Vol. 66 (4): 1163-1170.

http://dx.doi.org/10.1590/16786366

Muhammad, B., Dartosukarno S., dan Purnomoadi A. 2014. Tingkah Laku Makan Domba Lokal Jantan yang Diberi Pakan pada Waktu Siang dan Malam Hari. Animal Agriculture Journal (3) 4 . EjournalS1.undip.ac.id. (tersedia, 05-072018).
Nugroho, T. A., W. S. Dilaga, dan A. Purnomoadi. 2015. Eating Behaviour of Sheep Fed at Day and/or Night Period. Journal of the Indonesian Animal Agriculture. 40(3) Hal. 176-182. pISSN 20878273; eISSN 2460-6278.

Soeharsono, Lovita, A., Elvia, H., Andy, M., dan Kurnia A. K. 2010. Fisiologi Ternak Fenomena dan Nomena Dasar dari Fungsi serta Interaksi Organ pada Hewan. Widya Padjadjaran. Bandung. 191-216.

Soeparno. 1992. Ilmu dan teknologi daging. UGM Press: Yogyakarta.

Standar Nasional Indonesia 7532. 2009. Bibit Domba Garut. Badan Standardisasi Nasional Indonesia. Jakarta.

Sudjana. 2005. Metoda Statistika. Tarsito. Bandung. Hal: 161-168.

Supratman, Hery., Hendi Setiyatwan, Dwi Cipto Budinuryanto, Anita Fitriani, dan Dicky Ramdani. 2016. Pengaruh Imbangan Hijauan dan Konsentrat Pakan Komplit Terhadap Konsumsi, Pertambahan Bobot Badan dan Konversi Pakan Domba. Jurnal Ilmu Ternak, Juni 2016, Volume 16 No. 1. Hal. 31-35. https://doi.org/10.24198/jit.v16i1.9 822

Susiloningsih, I. Megakusuma, Soedarsono, E. Rianto, A. Purnomoadi. 2008. Pemanfaatan Protein Pada Domba Lokal Akibat Perbedaan Suhu Lingkungan. Seminar Nasional Teknologi Peternakan dan Veteriner 2008. Hal. 477-482.

Tama, Wahyu A., Moch. Nasich, Sri Wahyuningsih. 2016. Hubungan Antara Lingkar Dada, Panjang dan Tinggi Badan dengan Bobot Badan Kambing Senduro Jantan di Kecamatan Senduro, Kabupaten Lumajang. Jurnal Ilmu-Ilmu Peternakan. 26 (1): 37-42. ISSN: 0852-3681; E-ISSN: 2443-0765.

Tiesnamurti Bess, dan Subandriyo. 2005. Tingkah Laku Beranak Domba Merino dan Sumatera yang Dikandangkan. Seminar Nasional 
Peternakan dan Veteriner 2005.

Jakarta. Hal: 505-511.

Wijaya, Gagah Hendra., Mohamad Yamin,

Henny Nuraini, dan Anita

Esfandiari. 2016. Performans

Produksi dan Profil Metabolik
Darah Domba Garut dan Jonggol yang Diberi Limbah Tauge dan Omega-3. Jurnal Veteriner. Juni 2016. Volume 17 No. 2. Hal. 246256. pISSN: 1411-8327; eISSN: 2477-5665. 